\title{
Why do travelers trust TripAdvisor? Antecedents of trust towards consumer-generated media and its influence on recommendation adoption and word of mouth ${ }^{\text {tr }}$
}

\author{
Raffaele Filieri $^{\text {a, }}{ }^{*}$, Salma Alguezaui ${ }^{\text {b }}$, Fraser McLeay ${ }^{\text {a }}$ \\ ${ }^{a}$ Newcastle Business School, Northumbria University, City Campus East 1, NE1 8ST, Newcastle upon Tyne, United Kingdom \\ ${ }^{\mathrm{b}}$ Research Assistant at Newcastle Business School, Northumbria University, United Kingdom
}

\section{H I G H L I G H T S}

- The study tests a model of antecedents and consequences of trust towards consumer-generated media (CGM).

- Information quality, website quality, and customer satisfaction influence trust towards CGM.

- Information quality predicts source credibility, customer satisfaction, and website quality.

- Trust influences consumers' intention to follow other users' advice and to foster positive word of mouth.

\section{A R T I C L E I N F O}

\section{Article history:}

Received 27 August 2014

Accepted 6 May 2015

Available online 4 June 2015

\section{Keywords:}

Electronic word of mouth

Online trust

Website quality

Information quality

Customer satisfaction Consumer-generated media

Recommendation adoption

Word of mouth
G R A P H I C A L A B S T R A C T

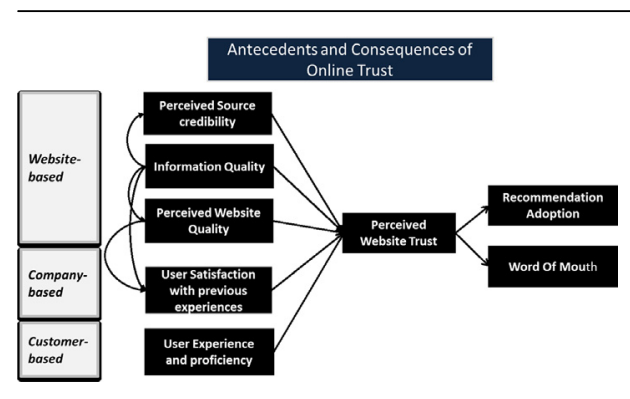


and agents altogether to get advice from consumer-generated media (CGM) - namely those websites that provide consumergenerated content (CGC) such as online consumer reviews. Travelers' recommendations on CGM influence consumer decisions of where to go on holiday, which accommodation to book, and once there, which attractions to visit and where to go to eat (Dickinger, 2011; Fotis, Buhalis, \& Rossides, 2012; Gretzel \& Yoo, 2008; Sparks, Perkins, \& Buckley, 2013). CGC such as online travel reviews allows consumers to identify the best hotels, restaurants, and attractions, enabling travelers to avoid the worst products and services, with the final result of improving their decision making (Filieri \& McLeay, 2014).

Tourism research has demonstrated that CGC is perceived as more trustworthy when compared to content from official destination websites, travel agents, and mass media (Dickinger, 2011; Fotis et al., 2012). However, in recent years the mass media all over the world have started to question the reliability of the most popular CGM, reporting stories of hotel managers posing as customers or encouraging their staff to write fake glowing reviews about their organization or even negative reviews about their competitors (e.g. Smith, 2013; Streitfield, 2011; Tuttle, 2012). In a bid to expose the apparent failure of TripAdvisor to tackle the phenomenon of fake reviews, a British businessman had set up a fake restaurant which started to receive glowing reviews (Smith, 2013). Thus, it has become apparent to many users that not all consumer reviews are necessarily written by real customers and opinion spam is widespread in consumer review websites (Jindal \& Liu, 2008).

Due to this apparently uncontrollable rise of fake and promotional content on CGM, a concept such as trust acquires a particular relevance. The questions that arise are: Why do travel consumers trust CGM like TripAdvisor? Does trust in CGM affect travel consumer behavior? The present research attempts to provide an answer to these questions. Although trust has been identified as a critical determinant of consumer purchase intentions in e-commerce (e.g. Flavián, Guinalíu, \& Gurrea, 2006; Hoffman, Novak, \& Peralta, 1999; Jarvenpaa, Tractinsky, \& Vitale, 2000; Lee \& Turban, 2001; Yoon, 2002), little attention has been paid to trust towards CGM (Ayeh, Au, \& Law, 2013a; Yoo \& Gretzel, 2009) and whether trust affects travel consumer behavior.

In order to fill this gap, this study has tested a new model measuring the antecedents and consequences of trust towards CGM. This study relies on the Beldad, de Jong, and Steehouder (2010) model of the antecedents of trust which attempts to measure the influence of factors like user experience, customer satisfaction, information quality, source credibility, and website quality, on trust towards CGM.

Furthermore, this research explores the influence of trust on two types of travel consumer behavior, namely: consumer intention to spread the word about the CGM website they use to other people in their network (word of mouth), and consumer intention to adopt the advice received from CGM and purchase the recommended product. These predictions were tested by using structural equation modeling with data from 366 travel users of CGM. The results have practical implications for travel operators and for managers of CGM and other online operators in the CGM industry.

The rest of the paper is structured as follows. First, we review the literature on electronic-word of mouth (e-WOM) and trust with a particular focus on CGM. We then present the theoretical framework and formulate the hypotheses of this study, subsequently we introduce the methodology and finally we present and discuss the findings. Managerial implications, limitations and future research directions conclude this paper.

\section{Online reviews, consumer-generated media and trust}

Consumers often try to get a feel for what a destination or accommodation will be like prior to their travel and for that reason they look for online consumer reviews on websites such as TripAdvisor, Yelp, and Holiday Watchdog. Online consumer reviews - also known in the literature as CGC - can be considered as a form of e-WOM, which refers to any positive or negative statement made by potential, actual or former consumers about a product or company, which is made available to a multitude of people and institutions via the Internet' (Hennig-Thurau, Gwinner, Walsh, \& Gremler, 2004, p. 39).

Existing research in e-WOM has primarily focused on the motivation of customers who write reviews (e.g. Hennig-Thurau et al., 2004), on the influence of consumer reviews on the purchase decisions of other customers (Senecal \& Nantel, 2004; Smith, Menon, \& Sivakumar, 2005), and on the role of consumer reviews in affecting the sales of different types of goods (Cui, Lui, \& Guo, 2012; Dellarocas, Zhang, \& Awad, 2007; Godes \& Mayzlin, 2004; Zhu \& Zhang, 2010).

Research in the travel and tourism industry has provided evidence that online consumer reviews influence hotel rooms sales (e.g. Ye, Law, \& Gu, 2009) and travelers' purchase intentions about which destination to travel to (Arsal, Backman, \& Baldwin, 2008), and which accommodation to book (e.g. Filieri \& McLeay, 2014; Gretzel \& Yoo, 2008; Sparks \& Browning, 2011; Vermeulen \& Seegers, 2009). Consumer-generated content have been found to be equally important with respect to officially provided information (Inversini, Cantoni, \& Buhalis, 2009). Websites like TripAdvisor have become so popular among travelers that they potentially influence the travel decisions of approximately 200 million users who visit the website each month to get recommendations over restaurants, accommodation, and destinations (TripAdvisor, 2014).

However, the mass media all over the world repeatedly report stories of fake and promotional reviews posted on CGM (e.g. Smith, 2013; Streitfield, 2011; Tuttle, 2012). TripAdvisor has recently been forced by the UK Advertising Standards Authority to remove its 'misleading' slogans referring to the trustworthy and honest nature of all the reviews hosted on its website. Thus, maintaining high levels of trust towards CGM seems to be an increasingly challenging task for the managers of these online organizations.

Trust is defined as 'one party's confidence in an exchange partner's reliability and integrity' (Morgan \& Hunt, 1994, p. 23). In this study, the focus is on online trust, which differs from offline trust in that the object of online trust can be a website (Bart, Shankar, Sultan, \& Urban, 2005), that is CGM websites in this study. Trust in an online retailer has been identified as a central success factor of e-commerce activities (e.g. Flavián et al., 2006; Hoffman et al., 1999; Jarvenpaa et al., 2000; Lee \& Turban, 2001; Yoon, 2002); however, little research has investigated the antecedents and the consequences of trust in e-WOM (Ayeh et al., 2013a). Existing research in e-tourism on this topic has investigated the impact of online travel reviews on the credibility of hotels (Sparks \& Browning, 2011), and the role that reviews play in reducing travelers' perceptions of risk when booking accommodation (Gretzel, Yoo, \& Purifoy, 2007). The study that more closely focuses on trust towards CGM is Ayeh et al. (2013a)'s on the determinants of travelers' attitudes and intentions towards usage of CGC for travel planning. Ayeh et al. (2013a) adopted the Technology Acceptance Model (TAM) to measure the impact of factors like usefulness, perceived ease of use, homophily, perceived source trustworthiness, and perceived enjoyment, which - with the exception of perceived trustworthiness - were found to contribute to intentions to use CGM for travel planning. However, in this study we adopt the trust-building model developed by Beldad et al. (2010), which will be discussed in the next section. 


\section{Theoretical background and research hypotheses}

The academic literature has identified several antecedents of trust and most of these studies focused on transacting websites (Beldad et al., 2010). Beldad et al. (2010) reviewed the literature on the antecedents of trust in commercial and non-commercial websites and classified them into three main categories: customer-based antecedents, such as users' experience with the technology used for the transaction, or user's tendency to trust; website-based antecedents, such as the quality of the website used or of the information; and organization/company-based antecedents such as customers' experiences with online organizations.

Beldad et al.'s (2010) framework has been adopted in this study to investigate the antecedents of trust towards CGM in the travel and tourism industry. The main reason for adopting Beldad et al. (2010)'s framework is that it is an online trust-building model that fits both commercial and non-commercial organizations, it has not yet received empirical validation for CGM websites, and includes a number of relationships that have not been tested before in a single model, which increases to the originality of the study.

However, it has to be noted that the Beldad et al. (2010) framework does not consider some of the peculiarities of CGM, which have been highlighted in e-WOM literature and therefore it has been adapted to fit the current research topic. For instance, popular CGM like TripAdvisor and Yelp are characterized by reviews posted by anonymous users on travel products and services such as attractions, accommodation, and restaurants available in a destination. A factor such as the credibility of the source will be more important in such a context. Moreover, the propensity to trust construct does not fit with the current study as this construct can be important for first-time users but irrelevant for returning users, which are the users we focus on in this study; therefore we have decided to drop this construct.

To summarize, in this study customer-based antecedents of trust included factors such as users' experience (knowledge and skills) in using CGM; website-based antecedents included website quality, information quality, and perceived source credibility; and organization/company-based antecedents included users' previous experiences with CGM. Furthermore, this study attempts to measure the consequences of trusting behavior towards CGM. Thus, we have considered whether trust influences the following consumer behaviors that are critical to the realization of the strategic objectives of CGM websites: following the recommendations of reviewers and purchasing the recommended product/service, and spreading positive word of mouth (WOM) about the CGM website.

\subsection{Website-based trust antecedents}

\subsubsection{Source credibility}

Source credibility and trustworthiness are considered to be fundamental predictors of consumers' acceptance of a message in traditional WOM (Hovland, Janis, \& Kelley, 1953; McGinnies \& Ward, 1980). Different than in face-to-face communications, in eWOM consumers cannot adopt paraverbal cues to assess the credibility of a communication source (Litvin et al., 2008; Tidwell \& Walther, 2002). Evaluating the credibility of a source is difficult in e-WOM communications (Park \& Lee, 2008) because reviews are written by anonymous sources who have no prior relationship with the receiver (Dellarocas, 2003).

Current research on the influence of source credibility on website trust is scant in e-WOM. Existing research has explored the influence of source credibility on perceived information usefulness (Cheung, Lee, \& Rabjhon, 2008; Willemsen, Neijens, Bronner, \& DeRidder, 2011), diagnosticity (Filieri, 2015), and information adoption with contrasting results (Zhang \& Watts, 2008). In the tourism literature,
Ayeh, Au, and Law (2013b) revealed a weak or non-significant relationship between source trustworthiness/expertise and intention to use user-generated content for travel planning.

However, more and more CGM require contributors to create a web profile when they register where they can provide some personal information (e.g. profile picture, places visited, and the like); additionally, most of these websites utilise reviewer reputation systems to enable consumers to assess the credibility of reviewers (Cheung, Luo, Sia, \& Chen, 2009). For example, TripAdvisor has introduced a badge system that show the different levels of expertise of reviewers, which can range from 'reviewer' to 'top contributor' depending on the number of reviews and posts published, while Yelp's users can acquire the 'elite' badge if they frequently provide high quality reviews and actively engage with the community.

Thus, all of this information may provide some sort of indication about the potential credibility and trustworthiness of a source. In this study, we argue that the perceived credibility of the source (reviewers) influences consumers' trust towards a channel of communication, namely a CGM website. We believe that if travel consumers perceive the reviewers as credible sources they will believe that the website is reliable in that it has effective mechanisms in place to avoid spammers who post deceptive reviews through fake accounts. Therefore, we hypothesize as follows:

\section{H1. Source credibility positively influences trust towards CGM.}

\subsubsection{Information quality}

Information quality refers to the quality of the information contained in an online review and is defined as the quality of the content of a consumer review from the perspective of information characteristics' (Park, Lee, \& Han, 2007, p. 128). Information quality in e-WOM reflects relevancy, sufficiency, accuracy, currency (Cheung et al., 2008; Park et al., 2007), value (Filieri \& McLeay, 2014), credibility and usefulness (Cheung et al., 2009) of the information. Information quality has been found to predict information adoption (Filieri \& McLeay, 2014) and purchase intentions (Park et al., 2007) and it is also a significant determinant of user trust in commercial websites (Kim, Xu, \& Koh, 2004), in health infomediaries (Zahedi \& Song, 2008), and an enabler of inter-organizational data interchange (Nicolaou \& McKnight, 2006).

Travel consumers retrieve reviews to make informed decisions about their travel options; however, the tourism product is complex as it is made up of multiple products and features, such as accommodation, transportation, restaurants, attractions and the like, so that consumers need to collect a large amount of information before being able to build their own travel package. Moreover, every consumer is different and has different needs; young married couples may be looking for romantic accommodation, while backpackers search for cheap and functional places to stay. A CGM that wants to satisfy such a wide variety of information needs must be able to provide information that is relevant to the different needs, current, and complete. Such information is valued highly if it is not biased by promotional messages from hotel managers (information credibility) and instead it is entirely based on real customers' experiences. In fact, the more credible the information is perceived to be, the more useful it is in making informed decisions (Cheung et al., 2009). Therefore, if travel consumers find that the information from reviews is credible, current, useful, valuable, sufficiently complete and relevant to satisfy their information needs, they will trust CGM more because they will think it comes from real customers and not from biased information sources. Thus, we propose:

H2. Information quality in reviews positively influences trust towards CGM. 
Additionally, the quality of information in online reviews is a very important cue for consumers to assess the credibility of a source (Filieri, 2015). An information source who provides current, accurate, complete, useful, and detailed information regarding the relevant features of a product may be perceived as more credible than a source who provides a short, superficial, emotional, and inaccurate description of a product. For this reason, we hypothesize as follows:

H2-1. Information quality positively influences perceived source credibility.

The quality of the information contained in online reviews can also be considered as an antecedent of perceived website quality. If the information retrieved on CGM is judged to be of high quality that means that the website fulfills consumers' expectations. The satisfaction that derives from retrieving highly valued content might be transferred to the functionalities of the website such as ease of navigation, security and privacy, speed of page loading and the like. As a consequence, travel consumers may perceive a CGM website to be of high quality as it enables them to effectively and efficiently retrieve all the information they need to make an informed decision. For this reason, we hypothesize as follows:

H2-2. Information quality positively influences perceived website quality.

Moreover, we argue that information quality predicts customer satisfaction with CGM. The main reason why consumers visit CGM is to retrieve travel information from other customers who have experienced a product or a service. If this information helps the travel consumer to effectively plan his/her trip and the website meets customer expectations, then he/she will be satisfied and will decide to return and use the website again in the future. Thus, we hypothesize as follows:

H2-3. Information quality positively influences customer satisfaction.

\subsubsection{Perceived CGM website quality}

Website quality refers to 'customers' perception of a website's performance in information retrieval and delivery' (Yang, Cai, Zhou, \& Zhou, 2005, p.579). In e-commerce literature, findings support the influence that website quality has on the formation of consumer trust in online merchants (McKnight, Choudhury, \& Kacmar, 2002). However, CGM websites like TripAdvisor do not enable transactions and so they function as information presenting and communication websites (Yang et al., 2005). Thus, the website quality of nontransacting websites includes factors such as ease of navigation, interactive communication and customization, technical adequacy, privacy, and security (Yang et al., 2005). In online environments, the website is faceless, so the interface becomes the 'online storefront' upon which first impressions are formed (McKnight et al., 2002). If a CGM is perceived as safe and secure, eases consumers' navigation and the retrieval of information through customized search engines and has forums where customers can interact with other customers, the user of such CGM will form a positive impression of the CGM website, which ultimately will be perceived as reliable. Accordingly, we hypothesize as follows:

H3. Perceived website quality positively influences trust towards CGM.

Previous research in e-tourism reported that website quality has a direct and positive impact on customer satisfaction (Bai, Law, \& Wen, 2008). By facilitating customer-to-customer information sharing about travel experiences, CGM websites are empowering travelers as they are now capable of building a tourism package for themselves (Litvin et al., 2008). Following this literature, we argue that the more a website is effective in fulfilling consumers' needs and in facilitating them in accomplishing their tasks (e.g. building a tourism package), the higher will be their satisfaction. Accordingly, we hypothesize:

H3-1. Perceived website quality positively influences customer satisfaction.

\subsection{Company/organization-based antecedents of trust}

\subsubsection{Satisfaction from previous experiences}

In marketing literature, customer satisfaction is measured as the general satisfaction of a customer, which is based on all cumulative experiences with a company, a product or a service, thereby it is not the satisfaction resulting from a specific transaction, rather a global evaluation of the relationship history between the parties (Olsen \& Johnson, 2003). A previous positive transaction with online shopping determines customers' trust in the company (Casalo, Flavián, \& Guinaliu, 2007; Flavián et al., 2006; Pavlou, 2003; Yoon, 2002). Drawing from this literature we expect that users of CGM who are satisfied with their previous usage experiences will be more likely to trust a CGM. In fact, while planning their travels, users of CGM search for tips and advice that can help them improve their decision making. If the tips received meet or exceed the traveler's expectations then he/she will be satisfied with his/her information search experience. For instance, if online reviews from other travelers help users to discover attractions, accommodation or restaurants that they would not be able to discover through other information sources (e.g. travel guides, friends' and professionals' advice) then they will be satisfied or even delighted as they will feel empowered. On the contrary, if travel reviews are inaccurate, biased or seemingly fake they will be more likely to let users down and then generate disappointment. If consumers experience disappointment then they will tend not to trust the CGM as the negative experience will provide them with the evidence that the CGM is not capable or willing to block unreliable and misleading content from appearing on the website. Consumers who are satisfied with their previous experiences will feel more confident about the reliability of the recommendations received on the CGM. Thus, we hypothesize as follows:

H4. Satisfaction with previous experiences positively influences users' trust towards a CGM.

\subsection{Customer-based trust antecedents}

\subsubsection{User experience and proficiency}

The receiver of communications in e-WOM indicates a travel consumer that seeks advices and recommendations from a CGM. The level of experience in using CGM and online reviews in the decision making process can be an important factor to consider when investigating the antecedents of trust (Beldad et al., 2010). According to Brown, Borderick, and Lee (2007), lack of experience may lead to naivety and credibility being given to all information on the Internet. Some studies support this argument by indicating that higher levels of web experience are associated with low levels of trust in online organizations (Aiken \& Boush, 2006; Jarvenpaa et al., 2000). According to Aiken and Boush (2006) a possible explanation for this is that users with high levels of experience may have already accumulated sufficient knowledge of possibilities that things could go wrong any time online. According to Bart et al. (2005) more knowledge of and experience with the Internet 
can spur greater confidence in using it, which would inflate online trust. However, other studies have found that high levels of Internet experience affect consumers' tendency to trust Internet technology, thereby enhancing their trust in Internet-based transactions (Corbitt, Thanasankit, \& Yi, 2003).

In this study, we argue that a travel consumer who has accumulated experience with using online reviews and CGM may feel confident of not being deceived by unreliable websites or content. An experienced user may feel knowledgeable enough in how to spot unreliable websites and fake reviews. Instead, first-time users are less knowledgeable about CGM and unaware of how to tell whether a CGM is reliable or not. Thus, lower levels of expertise and knowledge in using online CGM may result in more cautious behavior towards online reviews and CGM. On the contrary, a user who is very experienced with online reviews will trust CGM because he/she has got enough knowledge and experience of the website and of the reviews, which enables him/her to confidently distinguish reliable from unreliable CGM websites. Thus, we hypothesize as follows:

H5. Customer experience with using CGM positively influences trust towards CGM.

\subsection{Behavioral consequences of trust towards CGM}

The value of a CGM is given by the number of people using it and by the influence it has in a specific industry. To provide an example, the higher the popularity and influence of TripAdvisor in the tourism industry, the more e-retailers in the same industry would be willing to pay for a sponsored link from this website. Such a business model sustains the revenues of this and many other CGM, which is based on selling leads to large e-retailers in the travel and tourism industry, including Booking.com, Agoda.com, Hotels.com, and many more. Therefore, two key performance indicators of CGM are customer base and influence on consumer decisions. In this study, it is expected that trust towards CGM can influence both consumers' intention to adopt the recommendations received and engage in positive WOM about the CGM to other people. Below the hypotheses of the study are presented.

\subsubsection{Recommendation adoption}

Information adoption is the process by which people purposefully engage in using information (Cheung et al., 2008;
Sussman \& Siegal, 2003). Research highlighted the influence of trusting beliefs and trusting intention on the user's intention to follow an e-retailer's advice (McKnight et al., 2002). In the context of CGM, a trustworthy website is believed to monitor the legitimacy of the reviews submitted by its users in the consumer's best interest, thereby decreasing the risks associated with being deceived by fake content. Thus, we argue that the users of CGM should consider whether the recommendations contained in consumer reviews can be relied upon in order to learn about the expected quality and performance of a product or service. If the users of a CGM believe that the recommendations hosted on that CGM are reliable, they will be more likely to adopt those recommendations in their decision making. On the contrary, if the website is perceived as unreliable, consumers will not adopt the recommendations as they do not want to risk being deceived. Therefore, the more consumers view CGM as trustworthy the more likely they will be to follow the advice received.

H6. Customer trust towards CGM positively influences recommendation adoption.

\subsubsection{Word of mouth}

There is a scarcity of studies in online settings about the role of trust on consumer's intention to engage in positive WOM. In this study, we argue that if travel consumers trust CGM, they will then be more willing to talk to their friends and acquaintances about the website and about the experiences they have with using it. In fact, a consumer who uses other consumers' recommendations is more likely to improve his/her decision making. For instance, through reading consumer reviews the travel consumer may experience accommodation, restaurants or visit attractions which are off the beaten track, and these experiences will motivate him/her to engage in WOM about the tips received from CGM to their friends. The more consumers are confident about the trustworthiness of a CGM website the more likely they will be to tell their friends and acquaintances where the advice came from because the risk of deception is very low(Fig. 1). For this reason, we hypothesize:

H7. Consumer trust towards CGM positively influences word of mouth.

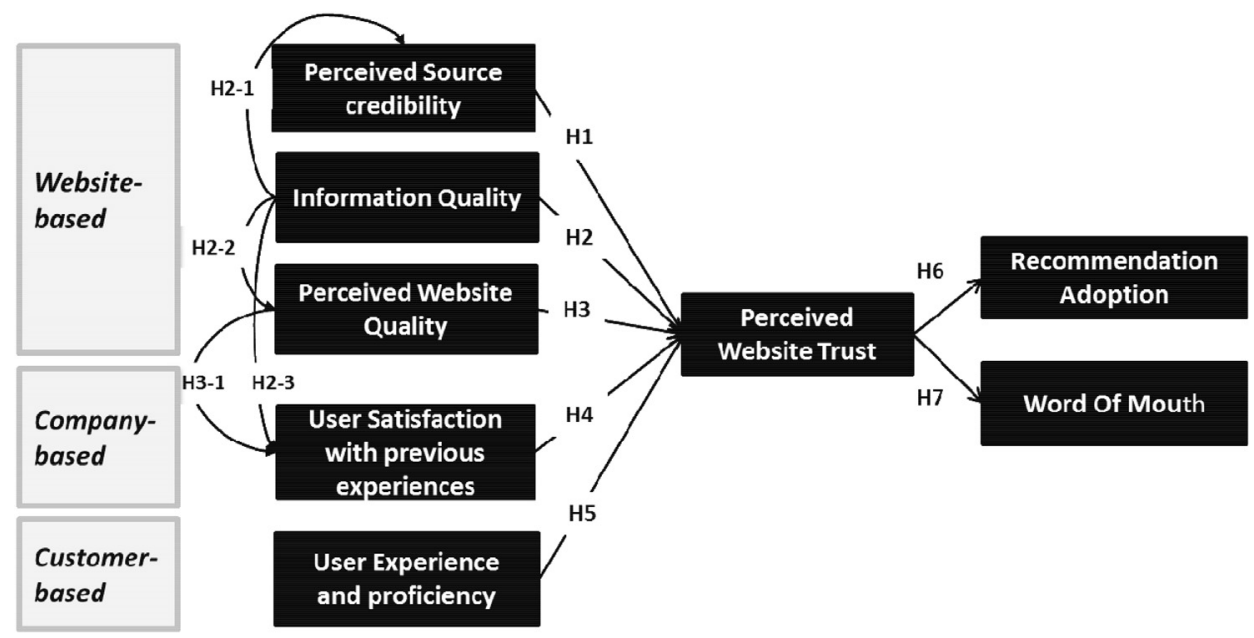

Fig. 1. Theoretical framework and hypotheses. 


\section{Methodology}

\subsection{Data collection}

Structural Equation Modeling (SEM) has been favored as a measurement technique over simple regression tools, because it enables researchers to test a series of dependence relationships simultaneously (Hair, Black, Babin, \& Anderson, 2010). The questionnaire for this study was created through a professional onlinebased survey tool, which has already been adopted in tourism research with satisfactory results (Ayeh et al., 2013a). The web questionnaire was primarily composed of closed questions that were measured using a 7-point Likert scale (see Table 2). The questionnaire was available in English and, prior to administration, it was pilot-tested with a total of 49 users of CGM, which led to paraphrasing and deleting items that were ambiguous or too similar to each other. An email with a link to the questionnaire was sent to a convenience sample of travel consumers among academic staff members and students from two universities located in the Republic of Ireland and in England. The focus on this European sample was decided in order to widen the geographical scope of e-WOM research as existing e-WOM studies are largely based on American and Asian consumers (Chan \& Ngai, 2011).

The travel consumers who participated to this study had recent experience in the use of CGM for tourism-related products and services (e.g. accommodation, restaurants), which was assessed in different ways: first, the email sent to potential respondents clearly stated that only people with recent experiences with CGM could participate in this study; second, the respondents were asked to write the name of the website where they read consumer reviews and indicate how frequently they used reviews before purchasing a travel product/service. A total of 401 responses were received; however, 35 questionnaires were discarded for different reasons such as outliers or missing cases, which yielded a total of 366 usable questionnaires.

\subsection{Measures}

The scale and items that were used to measure the constructs in this study are displayed in Table 2 and are derived from previous studies. Source credibility and trustworthiness were measured by a scale developed by Ohanian (1990) and recently used by Senecal and Nantel (2004) in e-WOM research. Information quality was measured through a scale used in previous studies in e-WOM (Cheung et al., 2009; Filieri \& McLeay, 2014; Park et al., 2007). The scale developed by Yang et al. (2005) for non-transacting websites was adopted to measure website quality for CGM and excluded the items measuring adequacy of information and usefulness of content because research has demonstrated that website quality and information quality are two different factors (DeLone \& McLean, 1992). The scale used to measure trust towards CGM was similar to a scale adopted in previous studies (Jarvenpaa et al., 2000; Kim, Ferrin, \& Rao, 2008). The scale used to measure users' experience with CGM and CGC was adapted from Smith et al. (2005). Customer satisfaction was measured with two items derived from Pavlou (2003), while information adoption was measured by a scale used in previous studies of online reviews (Cheung et al., 2009). e-WOM behavior was measured through a scale developed by Brown, Barry, Dacin, and Gunst (2005).

\subsection{Sample profile}

The socio-demographic characteristics of the sample are presented in Table 1 . The sample was primarily composed of
Table 1

Socio-demographic characteristics of the respondents.

\begin{tabular}{llc}
\hline Dimension & Items & Percentage \\
\hline Gender & $\mathrm{F}$ & 46.7 \\
Age & $\mathrm{M}$ & 53.3 \\
& $18-25$ & 63.5 \\
& $26-35$ & 33.5 \\
& $36-45$ & 1.5 \\
Income & $46-54$ & 1.5 \\
& $70.000 €$ and above & 0.5 \\
& $50.000-69.000 €$ & 0.5 \\
& $30.000-49.000 €$ & 5.4 \\
& $10.000-29.000 €$ & 35.2 \\
Nationality & Under 9.999 $€$ & 36.6 \\
& No Answer & 21.8 \\
& Rep. of Ireland or UK & 92.9 \\
& Other European countries & 3.6 \\
& United States & 1.5 \\
\hline
\end{tabular}

individuals aged $18-35$ (97\% of the sample) from European countries, primarily from the UK and the Republic of Ireland. This sample composition may result from the questionnaire being available in English, which reduced the number of non-English speaking respondents. The age range can be considered a limitation; however, individuals in this age cohort use consumer reviews the most and the Internet penetration in these countries is among the highest in the world ( $84 \%)$, as demonstrated by a recent Nielsen study (2013).

\subsection{Data analysis}

The most fundamental assumption in multivariate data analysis is the normality of the data, which has been tested using the Kaiser-Meyer-Olkin measure of sampling adequacy which provided a value of 0.907 , indicating that the model is meritorious (Hair et al., 2010). Normality was also assessed through the skewness and kurtosis values (see Table 3 ), which did not exceed \pm 2.58 or \pm 1.96 ; thus, the distribution can be considered normal (Hair et al., 2010).

Both the convergent and discriminant validity of the model were tested. Convergent validity was assessed using the average variance extracted (AVE), Cronbach's Alpha, and Composite Reliability (CR). The factor loadings for all the constructs used in this study were higher than the recommended cut-off of 0.5 , with the exception of website security which was 0.475 and for this reason this item was removed. CR values (see Table 2 ) were well above the threshold of 0.6 (Fornell \& Larcker, 1981), thus demonstrating that the scales measure the concepts that they were designed to measure. Reliability was assessed for each construct with Cronbach's $\alpha$, which ranged from 0.815 (website trust) to 0.917 (source credibility), which signifies a very good level of reliability for the items and the scales that were used in this study (Nunnally, 1978). Discriminant validity was assessed through the average variance extracted (AVE) for each latent variable included in the model, which should be greater than the squared correlation estimate (Fornell \& Larcker, 1981). Table 3 shows that these requirements have been met. Moreover, all factor correlations were below the 0.85 threshold (Fornell \& Larcker, 1981).

The overall model fit was measured using the relative/ normed chi-square $\left(x^{2} / \mathrm{df}\right)$, yielding a value of $x^{2} / \mathrm{df}=1.995$, which is below the recommended threshold of 3 (Kline, 2011), the chisquared value was 961.378 and all factor loadings were statistically significant $(p=0.000)$. The goodness-of-fit index (GFI) was 0.905 , and the comparative fit index (CFI) was 0.946; thus, both were above the suggested cut-off of 0.9 (Hu \& Bentler, 1999). 
Table 2

Scales, Items, Factor Loadings, Cronbach's $\alpha$.

\begin{tabular}{|c|c|c|c|c|}
\hline Construct & Items & Factor loading & $\mathrm{CR}$ & Overall $\alpha$ \\
\hline Website Quality & This travel review website & & 0.926 & 0.830 \\
\hline (WEBQUAL) & 1. is easy to use & 0.849 & & \\
\hline \multirow{6}{*}{$\begin{array}{l}\text { (7-point, strongly disagree- } \\
\text { strongly agree) }\end{array}$} & $2 \ldots$ has well-organized hyperlinks & 0.727 & & \\
\hline & $3 \ldots$ has customized search functions & 0.873 & & \\
\hline & $4 \ldots$ provided opportunities to interact with other customers & 0.754 & & \\
\hline & $5 \ldots$ has high speed of page loading & 0.807 & & \\
\hline & $6 \ldots$ is easily accessible from different media & 0.857 & & \\
\hline & 7 ... guarantees users' privacy & 0.732 & & \\
\hline Information Quality & The information in online reviews was & & 0.902 & 0.865 \\
\hline (INFOQUAL) & 1. Timely & 0.807 & & \\
\hline \multirow{5}{*}{$\begin{array}{l}\text { (7-point, strongly disagree- } \\
\text { strongly agree) }\end{array}$} & 2. Relevant to my needs & 0.748 & & \\
\hline & 3. Complete for my needs & 0.786 & & \\
\hline & 4. Valuable & 0.778 & & \\
\hline & 5. Useful & 0.832 & & \\
\hline & 6. Credible & 0.717 & & \\
\hline Source Credibility (SC) & 1. The reviewers were credible & 0.862 & 0.878 & 0.917 \\
\hline \multirow{3}{*}{$\begin{array}{l}\text { (7-point, strongly disagree- } \\
\text { strongly agree) }\end{array}$} & $2 \ldots$ were experienced & 0.779 & & \\
\hline & 3 ... were trustworthy & 0.894 & & \\
\hline & $4 \ldots$ were reliable & 0.886 & & \\
\hline \multirow{2}{*}{$\begin{array}{l}\text { Customer Satisfaction (SAT) } \\
\text { (7-point, strongly disagree- } \\
\text { strongly agree) }\end{array}$} & $\begin{array}{l}\text { 1. I am satisfied with the information I have received from this travel } \\
\text { reviews website }\end{array}$ & 0.872 & 0.893 & 0.892 \\
\hline & 2. I am satisfied with my previous experiences with this website & 0.923 & & \\
\hline $\begin{array}{l}\text { Receiver Experience } \\
\text { (EXP) }\end{array}$ & $\begin{array}{l}\text { 1. Prior to your participation in this study, how would you rate your } \\
\text { level of experience in terms of using CGM? }\end{array}$ & 0.913 & 0.903 & 0.901 \\
\hline \multirow[t]{2}{*}{$\begin{array}{l}\text { (7-point, not experienced at } \\
\text { all - very experienced) }\end{array}$} & $\begin{array}{l}\text { 2. Prior to your participation in this study, how would you rate your } \\
\text { level of experience in terms of browsing CGM? }\end{array}$ & 0.904 & & \\
\hline & $\begin{array}{l}\text { 3. Prior to your participation in this study, how would you rate your } \\
\text { level of experience in terms of online recommendations? }\end{array}$ & 0.787 & & \\
\hline $\begin{array}{l}\text { Website Trust (WEBTRUS) } \\
\text { (7-point, strongly disagree }\end{array}$ & $\begin{array}{l}\text { 1. I think that the information offered by this travel reviews website } \\
\text { was sincere and honest }\end{array}$ & 0.857 & 0.879 & 0.815 \\
\hline \multirow[t]{2}{*}{-strongly agree) } & $\begin{array}{l}\text { 2. I think that the advice and recommendations given on this travel } \\
\text { reviews website are made in search of mutual benefit of both the } \\
\text { reviewer and customers }\end{array}$ & 0.856 & & \\
\hline & 3. This travel reviews website is trustworthy & 0.809 & & \\
\hline $\begin{array}{l}\text { Word of Mouth Behavior } \\
\text { (WOM) }\end{array}$ & $\begin{array}{l}\text { 1. I mentioned to others that I seek travel information from this } \\
\text { travel reviews website }\end{array}$ & 0.871 & 0.926 & 0.858 \\
\hline \multirow[t]{3}{*}{ (7-point, never-frequently) } & $\begin{array}{l}\text { 2. I made sure that others know that I rely on this review website for } \\
\text { travel information }\end{array}$ & 0.873 & & \\
\hline & 3. I spoke positively about this travel review website to others & 0.876 & & \\
\hline & $\begin{array}{l}\text { 4. I recommended this travel review website to close personal } \\
\text { friends }\end{array}$ & 0.859 & & \\
\hline $\begin{array}{l}\text { Recommendation Adoption } \\
\text { (ADO) }\end{array}$ & $\begin{array}{l}\text { 1. Online reviews made it easier for me to make purchase decision } \\
\text { (e.g., purchase or not purchase) }\end{array}$ & 0.849 & 0.898 & 0.896 \\
\hline \multirow[t]{4}{*}{$\begin{array}{l}\text { (7-point, strongly disagree } \\
\text {-strongly agree) }\end{array}$} & $\begin{array}{l}\text { 2. Online reviews have enhanced my effectiveness in making } \\
\text { purchase decision }\end{array}$ & 0.814 & & \\
\hline & $\begin{array}{l}\text { 3. Online reviews have motivated me to make a purchase decision } \\
\text { (purchase or not purchase) }\end{array}$ & 0.801 & & \\
\hline & $\begin{array}{l}\text { 4. The last time I read online reviews I adopted consumers' } \\
\text { recommendations }\end{array}$ & 0.799 & & \\
\hline & $\begin{array}{l}\text { 5. Information from review contributed to my knowledge of } \\
\text { discussed product/service }\end{array}$ & 0.725 & & \\
\hline
\end{tabular}

Table 3

Means, SD, correlations, and AVE.

\begin{tabular}{|c|c|c|c|c|c|c|c|c|c|}
\hline Variable & Mean & SD & Skew & Kurt & 1 & 2 & 3 & 4 & 5 \\
\hline 1.SC & 5.12 & 0.9918 & -0.666 & 1.079 & 0.734 & - & - & - & - \\
\hline 2.INFOQUAL & 5.22 & 0.9248 & -0.586 & 0.991 & 0.496 & 0.607 & - & - & - \\
\hline 3.WEBQUAL & 5.34 & 0.9689 & -0.688 & 0.624 & 0.525 & 0.554 & 0.643 & - & - \\
\hline 4.SAT & 5.65 & 1.0899 & -1.13 & 1.800 & 0.530 & 0.591 & 0.604 & 0.806 & - \\
\hline 5.EXP & 4.77 & 1.5338 & -0.494 & -0.572 & 0.290 & 0.301 & 0.290 & 0.415 & 0.757 \\
\hline
\end{tabular}

Note. Off-diagonal values are squared correlations and on-diagonal values are AVEs.

Note. All correlations were significant at $p<0.001$.

The root mean square error of approximation (RMSEA), which indicates the amount of error in the model, was 0.058 below the recommended cut-off of 0.06 (Hu \& Bentler, 1999; Kline, 2011). Overall, the structural equation model shows a good fit (see Table 4).

\section{Results}

The structural equation model was tested using the statistical software Amos 18.0, and the results are presented in Table 4. Based on the results, the strongest predictors of website trust were: information quality $(\beta=0.402 ; p<0.001 ; t=4.966)$; customer 
Table 4

Goodness of fit indexes and hypotheses.

\begin{tabular}{|c|c|c|c|c|c|c|c|}
\hline \multicolumn{2}{|c|}{$\begin{array}{l}\text { Goodness of fit of the } \\
\text { Model }\end{array}$} & \multirow{2}{*}{$\begin{array}{l}\text { Hypoth. } \\
\text { H1 }\end{array}$} & \multirow{2}{*}{$\begin{array}{l}\text { Relationship } \\
\text { SC-> WEBTRUS }\end{array}$} & \multirow{2}{*}{$\begin{array}{l}\text { Standard. Regression weight } \\
0.070\end{array}$} & \multirow{2}{*}{$\begin{array}{c}t \text { value } \\
1.049\end{array}$} & \multirow{2}{*}{$\begin{array}{l}\mathrm{R}^{2} \\
0.832\end{array}$} & \multirow{2}{*}{$\begin{array}{l}\text { Supported vs. Rejected } \\
\text { Rejected }\end{array}$} \\
\hline$x^{2} / \mathrm{df}$ & 1.995 & & & & & & \\
\hline GFI & 0.905 & $\mathrm{H} 2$ & INFOQUAL-> WEBTRUS & $0.402^{* * *}$ & 4.966 & 0.832 & Supported \\
\hline CFI & 0.946 & $\mathrm{H} 2-1$ & INFOQUAL-> SC & $0.694^{* * *}$ & 8.087 & 0.366 & Supported \\
\hline Chi-sq. & 961.378 & $\mathrm{H} 2-2$ & INFOQUAL->WEBQUAL & $0.454^{* * *}$ & 5.100 & 0.548 & Supported \\
\hline \multirow[t]{7}{*}{ RMSEA } & 0.058 & $\mathrm{H} 2-3$ & INFOQUAL-> SAT & $0.402^{* * *}$ & 5.382 & 0.812 & Supported \\
\hline & & $\mathrm{H} 3$ & WEBQUAL-> WEBTRUS & $0.279^{* * *}$ & 4.036 & 0.832 & Supported \\
\hline & & H3-1 & WEBQUAL->SAT & $0.195^{* *}$ & 2.337 & 0.812 & Supported \\
\hline & & $\mathrm{H} 4$ & SAT-> WEBTRUS & $0.381^{* * *}$ & 6.611 & 0.832 & Supported \\
\hline & & H5 & EXP-> WEBTRUS & -0.020 & 0.576 & 0.832 & Rejected \\
\hline & & H6 & WEBTRUS-> ADO & $0.630^{* * *}$ & 9.148 & 0.397 & Supported \\
\hline & & $\mathrm{H} 7$ & WEBTRUS-> WOM & $0.812^{* * *}$ & 10.317 & 0.778 & Supported \\
\hline
\end{tabular}

Note: ${ }^{* * *}$ indicates $\mathrm{p}<0.001,{ }^{* *}$ indicates $\mathrm{p}<0.01,{ }^{*}$ indicates $\mathrm{p}<0.1$, no star means non-significant.

satisfaction $(\beta=0.381 ; p<0.001 ; t=6.611)$; and website quality $(\beta=0.279 ; p<0.001 ; t=4.036)$. Contrary to our predictions, source credibility $(\beta=0.070, p<$ non-significant; $t=1.049)$ and receiver experience $(\beta=-0.020 ; p<$ non-significant; $t=0.576)$ did not exhibit a significant predictive power in their relationship with the dependent variable; thereby the results support hypotheses $\mathrm{H} 2, \mathrm{H} 3$, and $\mathrm{H} 4$, while $\mathrm{H} 1$ and $\mathrm{H} 5$ are rejected.

Findings also show that information quality is a significant and strong predictor of website quality $(\beta=0.454 ; p<0.001 ; t=5.100)$; of source credibility $(\beta=0.694 ; p<0.001 ; t=8.087)$; and of customer satisfaction $(\beta=0.402 ; p<0.001 ; t=5.382)$ together with website quality $(\beta=0.195 ; p<0.01 ; t=2.337)$.

Finally, the influence of website trust on respectively recommendation adoption $(\beta=0.630 ; p<0.001 ; t=9.148)$ and word of mouth ( $\beta=0.812 ; p<0.001 ; t=10.317$ ) is found to be positive, strong and highly significant; thus, both $\mathrm{H} 6$ and $\mathrm{H} 7$ are accepted.

\section{Discussion}

Nowadays, the reliability of recommendations hosted on CGM is threatened by the rise of fake and promotional content being posted by paid reviewers or by managers and staff of business organizations to boost sales. Trust is a key performance indicator for CGM organizations, whose influence depends on the number of users and visitors that rely on the recommendations of CGM to make a decision about the products and service they are planning on buying.

Distinct from prior e-WOM researchers who focused on the influence of reviews on travelers' purchase intentions (e.g. Vermeulen \& Seegers, 2009), and on sales (e.g. Ye et al., 2009), this study has investigated the antecedents and consequences of trust towards CGM. The tested model was adapted from Beldad et al. (2010) and included a number of factors that have not been tested before in a single model, which advances e-WOM theory. Thus, the theoretical implications of this research are that consumer trust towards CGM relies on three main antecedents: 1) those related to the quality of the information contained in online reviews; 2 ) those related to the quality of the website that hosts the recommendations; 3 ) those related to the level of customer satisfaction with previous experiences. It appears that the higher the quality of the information that consumers retrieve the more they will perceive the website to be of high quality, which will both lead to customer satisfaction and trust in the CGM website. The results have also proved that trust affects two types of consumer behavior: recommendation adoption and word of mouth.

This study's findings emphasize the centrality of information quality in CGM, which was found to be the most important antecedent of trust towards CGM, which accords with findings from previous research but in different contexts (Nicolaou \& McKnight, 2006; Zahedi \& Song, 2008). This result can be explained by the fact that consumers use CGM to obtain a type of information that is highly valuable and difficult to find in other media, namely reviews from previous customers who, by describing their previous experiences, help other consumers to assess the quality of the products and services they are planning to buy. If the information hosted on CGM fits consumer needs, is credible, current, complete, valuable and useful, consumers will rely on the recommendations provided on CGM. Therefore, the main reason consumers trust CGM is due to the quality of the recommendations that they receive, meaning that CGM offering high quality information are still perceived as trustworthy information channels. Consumers trust CGM as these websites give them the opportunity to read reviews from real customers, which is different than reading promotional content on corporate websites.

Information quality was also found to be a strong predictor of source credibility, website quality, and customer satisfaction. Interestingly, it is the quality of the information from online reviews that will provide consumers with an indication of the level of reliability of a source, which means that in the absence of verbal and paraverbal cues users of CGM will adopt information quality criteria related to the message of the review as a cue to assess the credibility of a source. This finding may be explained by the fact that users rarely check the profile information of reviewers, rather they prefer to process the relevant information from reviews that are likely to satisfy their need to assess the credibility of a source.

Additionally, users of CGM will use information quality cues to infer the quality of CGM websites. This finding may be due to the fact that the primary function of a CGM website is to provide customer accounts of their experience with products and services in the form of reviews, discussions, comments, ratings, and rankings. Thereby the higher the quality of the content hosted on CGM, the better consumer perception will be of the overall quality of the website.

Moreover, the quality of advice received is also the main reason why consumers are satisfied with their previous experiences with a CGM website. This result can be explained by the fact that travelers will feel empowered by using online customer reviews to inform their travel decisions, which will result in better travel experiences and consequently higher levels of satisfaction.

Our findings also show that satisfaction with previous experiences strongly predicts website trust, which agrees with previous findings in e-commerce research (e.g. Casalo et al., 2007; Flavián et al., 2006; Pavlou, 2003; Yoon, 2002). Satisfaction with previous experiences leads to trust towards CGM. The satisfaction of 
customers derives from receiving valuable, useful, and complete assessments from previous customers about the products and services that they are planning to buy. Although the mass media have repeatedly put in the pillory the incapability of review websites to tackle the phenomenon of fake reviews, customers are in general satisfied with their experiences with CGM and trust them. Thus, if the quality of information is kept high on CGM, consumers will be satisfied and they will continue trusting CGM websites.

Website quality emerged as a strong predictor of website trust and of customer satisfaction. Thus, the higher the perceived quality of a CGM website in terms of its capability to enable (also through customized search functions) consumers easy and rapid access to the information they are looking for from different devices (e.g. smartphone), to interact with other consumers, to guarantee their privacy, the more consumers will trust and will be satisfied with CGM. Thus, this study shows that website quality is an important predictor of trust and customer satisfaction not only for e-commerce websites (e.g. Bai et al., 2008; McKnight et al., 2002), but also for CGM websites.

Research on source credibility in e-WOM has mostly focused on its influence on consumer decisions (Zhang \& Watts, 2008), consumer intentions to use user-generated content (Ayeh et al., 2013b), and information diagnosticity (Filieri, 2015). This study has instead measured the relationship between source credibility and trust towards a type of online media, namely CGM. Findings show that source credibility does not exercise a strong influence on the reliability of CGM. This result may be due to the fact that consumers may be aware that fake profiles can be created easily on CGM websites (Dellarocas, 2003) and that not all the sources that publish reviews can be considered as credible and trustworthy; however, they are confident that the wisdom of the crowd will emerge and that a few fake profiles or low quality reviews cannot skew the overall positive evaluation that customers have of CGM websites.

It was found that the level of experience of the receiver in terms of browsing and using CGM was not a significant predictor of trust towards CGM. This means that trust evaluations of CGM will be almost the same between experienced and inexperienced users. However, on average, users with more experience with CGM will tend to trust CGM less than novice users.

Results have proved that trust predicts information adoption in CGM websites and word of mouth, which advances e-WOM literature as previous research found that information usefulness and credibility both predicted information adoption (Cheung et al., 2008; 2009). This result means that the higher the quality of recommendations and the more a CGM is perceived as trustworthy, the higher will be its influence on consumers' purchasing decisions. Thus, the element that will distinguish how influential CGM are will be the level of trustworthiness ascribed to them by users. Simply put, trust is a critical performance indicator for CGM and must be constantly monitored.

Finally, the more consumers perceive a CGM to be trustworthy the more they are willing to talk to their friends about it. Therefore, if CGM websites want to increase their popularity among customers, they have to be trusted, as trust will motivate its users to talk to their friends about their positive experience with the recommendation received from the CGM website. This way, these organizations will save a huge amount of money on advertising as their consumers will informally publicize the website in their social circles, and following a network effect, the name of the website will spread quickly among Internet users. Therefore, keeping high levels of trust can be critical also to enlarge the customer base and increase the popularity and reach of a CGM website.

\section{Managerial implications}

Trust has become a top concern for CGM as evidenced by a pop-up message on Yelp: 'Your trust is our top concern, so businesses can't pay to alter or remove their reviews'. Failure on the part of these organizations to maintain high levels of trust among their users could significantly thwart users from engaging in information search from CGM, which can then undermine the influential power that they have in a specific industry. This study has provided empirical validation of a model that can help managers of these organizations to understand the drivers and consequences of trust to their CGM website. Information quality emerged as a critical success factor for CGM, thus managers of these organizations should put a stronger focus on this aspect because by increasing the quality of the information provided by their users they can improve customer satisfaction, website quality and website trustworthiness perceptions, which could boost their popularity and increase their influence in the industry.

Keeping the quality of information provided by reviewers high is a major challenge for CGM as publishing fake reviews by posing as a customer is relatively easy and the tendency to pay for promotional reviews is expected to grow in the future (Gartner, 2012). The growth of fake reviews might affect the quality of the information hosted by CGM as consumers will have to figure out how to identify credible and discard potentially fake reviews. Considering the proven importance of the level of quality of the information hosted on CGM, the tendency to bias reviews and ratings may have a negative impact on the level of trust towards CGM, and as a consequence on their influence on consumer decisions and on word of mouth. Thus, we recommend that CGM should foster the development of sophisticated software or algorithms that can help them to promptly detect promotional or fake reviews. Websites like TripAdvisor will need to be significantly more vigilant in their quest to ensure that all reviews and ratings are genuine and trustworthy.

Another recommendation for CGM to keep high levels of trust would be to ask reviewers to post a picture of their receipt or any other evidence of their purchase in order to communicate reliability. Additionally, the most active members of a CGM community could be engaged to constantly monitor the quality of the entries. In fact, some of these users (e.g. Destination experts in TripAdvisor) are so committed to CGM that they may be willing to spend even more time to help the website to keep out the shills from business owners, their friends, and employees.

\section{Limitations and future research}

The present study has some limitations. First, the sample was primarily composed of respondents from the UK and Republic of Ireland. Although our findings may generally apply to similar cultural contexts, results may not be generalizable to other geographical areas. For instance, differences in cultural background may affect the antecedents of trust towards websites (Doney, Cannon, \& Mullen, 1998; Jarvenpaa, Tractinsky, \& Saarinen, 1999). Moreover, the size of the sample was relatively small. Therefore, future research should replicate the study in other contexts and with a larger sample size.

This study was focused on actual users of CGM; however, scholars have investigated the role of trust by identifying different stages: an 'exploratory stage' in which a consumer has no direct experience with an electronic vendor, and a 'commitment stage' in which the consumer has accumulated some experience and decide to carry out higher risk operations (McKnight, Choudhury, \& Kacmar, 2000). This study has focused on the commitment stage; however, future research could be undertaken on first-time users of CGM and could investigate the influence of factors like the propensity to trust, trust marks, and website reputation which are deemed to be important in the exploratory stage (Beldad et al., 2010). 
Moreover, the present study suffers the typical limitations of cross-sectional studies based on SEM. Cross-sectional data require the assumption of equilibrium and provide only a 'snapshot' of an ongoing dynamic process (Kaplan, Harik, \& Hotchkiss, 2001). A longitudinal approach in the analysis of trust towards CGM is recommended to verify and extend the findings of this research. Data collected at different points in time would enable a test of the predictive validity of the model (between antecedents and trust, or between trust and outcome measures). A longitudinal study would be useful to measure stability versus change in rank order and to understand how trust in CGM evolves over time.

It is important to note that our research model examined perceived website trust and its influence on intention behavior (e.g. recommendation adoption and WOM) rather than actual behavior. Therefore future research should measure the behavioral outcomes of trust. In order to do so, scholars could carry out experiments where respondents are divided into separate groups and are instructed to browse different CGM before purchasing tourismrelated products and services. Since trust may develop differently in different kinds of CGM such as blogs, microblogging websites, and social network websites, experiments could also enable a test for consumer perception of trust towards different CGM.

This study has measured the influence of information quality on trust towards CGM. Information quality was measured as a composite construct including information value, completeness, timeliness, usefulness, relevancy, credibility. However, scholars could explore the influence of the different dimensions of information quality on website trust to see which dimension matters the most.

\section{Contribution}

Dr.Raffaele Filieri was the main contributor to the full production of this article which draws upon research undertaken in a joint research project with Salma Alguezaui and Professor Fraser McLeay. Kindly note Salma Alguezaui is a PhD student at Universita del Salento Departimento di Igegneria dell' Innovazione,Italy,and a Research Assistant at Northumbria University.

\section{Acknowledgments}

I'd like to thank the editor and three reviewers for their constructive and helpful comments, prof. Fraser McLeay for his comments on the questionnaire, and Nigel Coates for his helpful comments on some sections of the paper.

\section{Appendix 1}

\begin{tabular}{|c|c|c|c|}
\hline Scale & Item & Mean & SD \\
\hline \multirow{9}{*}{$\begin{array}{l}\text { Website Quality (WEBQUAL) } \\
\text { (7-point, strongly disagree- } \\
\text { strongly agree) }\end{array}$} & This travel review website is & & \\
\hline & 1. easy to use & 5.6 & 1.18 \\
\hline & 2 ... well-organized hyperlinks & 5.0 & 1.36 \\
\hline & $3 \ldots$ customized search functions & 5.6 & 1.34 \\
\hline & $4 \ldots$ provided opportunities to interact with other customers & 4.9 & 1.69 \\
\hline & $5 \ldots$ high speed of page loading & 5.4 & 1.34 \\
\hline & $6 \ldots$ is easily accessible from different media & 5.9 & 1.17 \\
\hline & 7 ... guarantees users' privacy & 5.0 & 1.45 \\
\hline & $8 \ldots$ is secure* & 4.3 & 1.72 \\
\hline \multirow{2}{*}{$\begin{array}{l}\text { Information Quality } \\
\quad \text { (INFOQUAL) }\end{array}$} & The information in online reviews was & & \\
\hline & 1. Timely & 5.0 & 1.25 \\
\hline \multirow{5}{*}{$\begin{array}{l}\text { (7-point, strongly disagree- } \\
\text { strongly agree) }\end{array}$} & 2. Relevant to my needs & 5.5 & 1.13 \\
\hline & 3. Complete for my needs & 5.0 & 1.29 \\
\hline & 4. Valuable & 5.5 & 1.21 \\
\hline & 5. Useful & 5.1 & 1.37 \\
\hline & 6. Credible & 5.2 & 1.24 \\
\hline Source Credibility (SC) & 1. The reviewers were credible & 5.2 & 1.13 \\
\hline \multirow{3}{*}{$\begin{array}{l}\text { (7-point, strongly disagree- } \\
\text { strongly agree) }\end{array}$} & $2 \ldots$ were experienced & 5.1 & 1.21 \\
\hline & 3 ... were trustworthy & 5.0 & 1.18 \\
\hline & $4 \ldots$ were reliable & 5.1 & 1.16 \\
\hline Customer Satisfaction (SAT) & 1. I am satisfied with the information I have received from this travel reviews website & 5.7 & 1.25 \\
\hline $\begin{array}{l}\text { (7-point, strongly disagree- } \\
\text { strongly agree) }\end{array}$ & 2. I am satisfied with my previous experiences with this website & 5.6 & 1.17 \\
\hline $\begin{array}{l}\text { Receiver Experience } \\
\text { (EXP) }\end{array}$ & $\begin{array}{l}\text { 1. Prior to your participation in this study, how would you rate your level of experience in } \\
\text { terms of using CGM? }\end{array}$ & 4.7 & 1.65 \\
\hline \multirow[t]{2}{*}{$\begin{array}{l}\text { (7-point, not experienced at all } \\
\text { - very experienced) }\end{array}$} & $\begin{array}{l}\text { 2. Prior to your participation in this study, how would you rate your level of experience in } \\
\text { terms of browsing CGM }\end{array}$ & 4.7 & 1.70 \\
\hline & $\begin{array}{l}\text { 3. Prior to your participation in this study, how would you rate your level of experience in } \\
\text { terms of online recommendations? }\end{array}$ & 4.9 & 1.67 \\
\hline Website Trust (WEBTRUS) & 1. I think that the information offered by this travel reviews website was sincere and honest & 5.5 & 1.16 \\
\hline \multirow[t]{2}{*}{$\begin{array}{l}\text { (7-point, strongly disagree } \\
\text {-strongly agree) }\end{array}$} & $\begin{array}{l}\text { 2. I think that the advice and recommendations given on this travel reviews website are } \\
\text { made in search of mutual benefit of both the reviewer and customers }\end{array}$ & 5.5 & 1.20 \\
\hline & 3. This travel reviews website is trustworthy & 5.4 & 1.19 \\
\hline \multirow{4}{*}{$\begin{array}{l}\text { Word of Mouth Behavior } \\
\text { (WOM) } \\
\text { (7-point, never-frequently) }\end{array}$} & 1. I mentioned to others that I seek travel information from this travel reviews website & 5.7 & 1.28 \\
\hline & 2. I made sure that others know that I rely on this review website for travel information & 5.6 & 1.25 \\
\hline & 3. I spoke positively about this travel review website to others & 5.5 & 1.44 \\
\hline & 4. I recommended this travel review website to close personal friends & 5.9 & 1.23 \\
\hline \multirow{5}{*}{$\begin{array}{l}\text { Recommendation Adoption } \\
\text { (ADO) } \\
\text { (7-point, strongly disagree } \\
\quad \text {-strongly agree) }\end{array}$} & $\begin{array}{l}\text { 1. Online reviews made it easier for me to make purchase decision (e.g., purchase or not } \\
\text { purchase) }\end{array}$ & 5.9 & 1.28 \\
\hline & 2. Online reviews have enhanced my effectiveness in making purchase decision & 5.8 & 1.15 \\
\hline & 3 ... have motivated me to make a purchase decision (purchase or not purchase) & 5.7 & 1.29 \\
\hline & 4. The last time I read online reviews I adopted consumers' recommendations & 5.4 & 1.29 \\
\hline & 5. Information from review contributed to my knowledge of discussed product/service & 5.7 & 1.19 \\
\hline
\end{tabular}

*This item was removed from the analysis. 


\section{References}

Aiken, K. D., \& Boush, D. M. (2006). Trustmarks, objective-source ratings, and implied investments in advertising: investigating online trust and the contextspecific nature of internet signals. Journal of the Academy of Marketing Science, 34(3), 308-323.

Arsal, I., Backman, S., \& Baldwin, E. (2008). Influence of an online travel community on travel decisions. In P. O'Connor, W. Höpken, \& U. Gretzel (Eds.), Information and communication technologies in tourism 2008 (pp. 82-93). Vienna, Austria: Springer-Verlag.

Ayeh, J. K., Au, N., \& Law, R. (2013a). Predicting the intention to use consumergenerated media for travel planning. Tourism Management, 35(April), 132-143.

Ayeh, J. K., Au, N., \& Law, R. (2013b). Do we believe in TripAdvisor? Examining credibility perceptions and online travelers' attitude toward using usergenerated content. Journal of Travel Research, 52(4), 437-452.

Bai, B., Law, R., \& Wen, I. (2008). The impact of website quality on customer satisfaction and purchase intentions: evidence from Chinese online visitors. International Journal of Hospitality Management, 27(3), 391-402.

Bart, Y., Shankar, V., Sultan, F., \& Urban, G. L. (2005). Are the drivers and role of online trust the same for all web sites and consumers? A large-scale exploratory empirical study. Journal of Marketing, 69(4), 133-152.

Beldad, A., de Jong, M., \& Steehouder, M. (2010). How shall I trust the faceless and the intangible? A literature review on the antecedents of online trust. Computers in Human Behavior, 26(5), 857-868.

Brown, T. J., Barry, T. E., Dacin, P. A., \& Gunst, R. F. (2005). Spreading the word: investigating antecedents of consumers' positive word of mouth intentions and behaviors in a retailing context. Journal of the Academy of Marketing Science, 33(2), 123-138.

Brown, J., Broderick, A. J., \& Lee, N. (2007). Word of mouth communication within online communities: conceptualizing the online social network. Journal of Interactive Marketing, 21(3), 2-20.

Buhalis, D., \& Law, R. (2008). Progress in information technology and tourism management: 20 years on and 10 years after the internet-The state of eTourism research. Tourism Management, 29(4), 609-623.

Casalo, L. V., Flavián, C., \& Guinaliu, M. (2007). The influence of satisfaction, perceived reputation and trust on a consumer's commitment to a website. Journal of Marketing Communications, 13(1), 1-17.

Chan, Y. Y. Y., \& Ngai, E. W. T. (2011). Conceptualising electronic word of mouth activity: an input-process-output perspective. Marketing Intelligence \& Planning, 29(5), 488-516.

Cheung, C. M. K., Lee, M. K. O., \& Rabjhon, N. (2008). The impact of electronic wordof-mouth: the adoption of online opinions in online customer communities. Internet Research, 18(3), 229-247.

Cheung, M. Y., Luo, C., Sia, C. L., \& Chen, H. (2009). Credibility of electronic word-ofmouth: informational and normative determinants of on-line consumer recommendations. International Journal of Electronic Commerce, 13(4), 9-38.

Corbitt, B. J., Thanasankit, T., \& Yi, H. (2003). Trust and e-commerce: a study of consumer perceptions. Electronic Commerce Research and Applications, 2(3), 203-215.

Cui, G., Lui, H.-K., \& Guo, X. (2012). The effect of online consumer reviews on new product sales. International Journal of Electronic Commerce, 17(1), 39-58.

Dellarocas, C. (2003). The digitization of word of mouth: promise and challenges of online feedback mechanisms. Management Science, 49(10), 1407-1424.

Dellarocas, C., Zhang, X. M., \& Awad, N. F. (2007). Exploring the value of online product reviews in forecasting sales: the case of motion pictures. Journal of Interactive Marketing, 21(4), 23-45.

DeLone, W. H., \& McLean, E. R. (1992). Information systems success: the quest for the dependent variable. Information Systems Research, 3(1), 60-95.

Dickinger, A. (2011). The trustworthiness of online channels for experience- and goal-directed search tasks. Journal of Travel Research, 50(4), 378-391.

Doney, P. M., Cannon, J. P., \& Mullen, M. R. (1998). Understanding the influence of national culture on the development of trust. Academy of Management Review, 23(3), 601-620.

Filieri, R. (2015). What makes online reviews helpful? A diagnosticity-adoption framework to explain informational and normative influences in e-WOM. Journal of Business Research, 68(6), 1261-1270.

Filieri, R. \& McLeay, F (2014). E-WOM and accommodation: an analysis of the factors that influence travelers' adoption of information from online reviews. Journal of Travel Research, 53(1), 44-57.

Flavián, C., Guinalíu, M., \& Gurrea, R. (2006). The role played by perceived usability, satisfaction and consumer trust on website loyalty. Information \& Management 43(1), 1-14.

Fornell, C., \& Larcker, D. F. (1981). Evaluating structural equation models with unobserved variables and measurement error. Journal of Marketing Research, 18(1), 39-50.

Fotis, J., Buhalis, D., \& Rossides, N. (2012). Social media use and impact during the holiday travel planning process. In M. Fuchs, F. Ricci, \& L. Cantoni (Eds.), Information and communication technologies in tourism 2012 (pp. 13-24). Vienna, Austria: Springer-Verlag.

Gartner. (2012, September 17). Gartner says by 2014, 10-15 percent of social media reviews to be promotional, paid for by companies [Press release]. Retrieved from http://www.gartner.com/newsroom/id/2161315.

Godes, D., \& Mayzlin, D. (2004). Using online conversations to study word of mouth communication. Marketing Science, 23(4), 545-560.
Gretzel, U., \& Yoo, K. H. (2008). Use and impact of online travel reviews. In P. O'Connor, W. Hopken, \& U. Gretzel (Eds.), Information and communication technologies in tourism 2008 (pp. 35-46). Vienna, Austria: Springer-Verlag.

Gretzel, U., Yoo, K. H., \& Purifoy, M. (2007). Online travel review study: Role and impact of online travel reviews. Austin, TX: Laboratory for Intelligent Systems in Tourism, Texas A\&M University.

Hair, J. F., Black, W. C., Babin, B. J., \& Anderson, R. E. (2010). Multivariate data analysis (7th ed.). Upper Saddle River, New Jersey: Prentice Hall.

Hennig-Thurau, T., Gwinner, K. P., Walsh, G., \& Gremler, D. D. (2004). Electronic word of mouth via consumer-opinion platforms: what motivates consumers to articulate themselves on the internet? Journal of Interactive Marketing, 18(1), $38-52$.

Hoffman, L. D., Novak, T. P., \& Peralta, M. (1999). Building consumer trust online. Communications of the ACM, 42(4), 80-85.

Hovland, C. I., Janis, I. L., \& Kelley, H. H. (1953). Communication and persuasion; psychological studies of opinion change. New Haven, CT: Yale University Press.

Hu, L. T., \& Bentler, P. M. (1999). Cutoff criteria for fit indexes in covariance structure analysis: conventional criteria versus new alternatives. Structural Equation Model: A Multidisciplinary Journal, 6(1), 1-55.

Inversini, A., Cantoni, L., \& Buhalis, D. (2009). Destinations' information competition and web reputation. Information Technology \& Tourism, 11(3), 221-234.

Jarvenpaa, S. L., Tractinsky, N., \& Saarinen, L. (1999). Consumer trust in an internet store: a cross-cultural validation. Journal of Computer-Mediated Communication, $5(2)$.

Jarvenpaa, S. L., Tractinsky, N., \& Vitale, M. (2000). Consumer trust in an internet store. Information Technology and Management, 1(1/2), 45-72.

Jindal, N., \& Liu, B. (2008). Opinion spam and analysis. February 11-12. In Proceedings of the Conference on Web Search and Web Data Mining (WSDM'08) (pp. 219-230). Palo Alto: California, USA.

Kaplan, D., Harik, P., \& Hotchkiss, L. (2001). Cross-sectional estimation of dynamic structural equation models in disequilibrium. In R. Cudeck, S. du Toit, \& S. Sörbom (Eds.), Structural equation modeling: Present and future (pp. 315-340). Lincolnwood, IL: Scientific Software International.

Kim, D. J., Ferrin, D. L., \& Rao, H. R. (2008). A trust-based consumer decision-making model in electronic commerce: the role of trust, perceived risk, and their antecedents. Decision Support Systems, 44(2), 544-564.

Kim, H., Xu, Y., \& Koh, J. A. (2004). A comparison of online trust building factors between potential customers and repeat customers. Journal of the Association for Information Systems, 5(10), 392-420.

Kline, R. B. (2011). Principles and practice of structural equation modeling. New York NY: Guilford press.

Lee, M. K., \& Turban, E. (2001). A trust model for consumer internet shopping. International Journal of Electronic Commerce, 6(1), 75-91.

Litvin, S., Goldsmith, R., \& Pan, B. (2008). Electronic word of mouth in hospitality and tourism management. Tourism Management, 29(3), 458-468.

McGinnies, E., \& Ward, C. D. (1980). Better liked than right: trustworthiness and expertise as factors in credibility. Personality and Social Psychology Bulletin, 6(3), 467-472.

McKnight, D. H., Choudhury, V., \& Kacmar, C. (2000). Trust in e-commerce vendors: a two-stage model. In Proceedings of the 21st International Conference on Information Systems (pp. 532-536). Brisbane, Australia: Association for Information Systems.

McKnight, D. H., Choudhury, V., \& Kacmar, C. (2002). The impact of initial consumer trust on intentions to transact with a web site: a trust building model. Journal of Strategic Information Systems, 11(3-4), 297-323.

Morgan, R. M., \& Hunt, S. D. (1994). The commitment-trust theory of relationship marketing. Journal of Marketing, 58(3), 20-38.

Nicolaou, A. I., \& McKnight, D. H. (2006). Perceived information quality in data exchanges: effects on risk, trust, and intention to use. Information Systems Research, 17(4), 332-351.

Nielsen. (2013, June 27). The reviews are in: yelp users are four-star consumers. Retrieved from http://www.nielsen.com/us/en/insights/news/2013/thereviews-are-in-yelp-users-are-four-star-consumers.html.

Nunnally, J. C. (1978). Psychometric theory (2nd ed.). New York, NY: McGraw-Hill.

Ohanian, R. (1990). Construction and validation of a scale to measure celebrity endorsers' perceived expertise, trustworthiness, and attractiveness. Journal of Advertising, 19(3), 39-52.

Olsen, L. L., \& Johnson, M. D. (2003). Service equity, satisfaction, and loyalty: from transaction-specific to cumulative evaluations. Journal of Service Research, 5(3), 184-195.

Park, D.-H., \& Lee, J. (2008). E-WOM overload and its effect on consumer behavioural intention depending on consumer involvement. Electronic Commerce Research and Applications, 7(4), 386-398.

Park, D.-H., Lee, J., \& Han, I. (2007). The effect of online consumer reviews on consumer purchasing intention: the moderating role of involvement. International Journal of Electronic Commerce, 11(4), 125-148.

Pavlou, P. A. (2003). Consumer acceptance of electronic commerce: integrating trust and risk with the technology acceptance model. International Journal of Electronic Commerce, 7(3), 101-134.

Senecal, S., \& Nantel, J. (2004). The influence of online product recommendations on consumers' online choices. Journal of Retailing, 80(2), 159-169.

Smith, O. (2013, July 25). TripAdvisor fails to spot fake restaurant. The Telegraph. Retrieved from http://www.telegraph.co.uk/travel/travelnews/10201754/Trip Advisor-fails-to-spot-fake-restaurant.html. 
Smith, D., Menon, S., \& Sivakumar, K. (2005). Online peer and editorial recommendations, trust and choice in virtual markets. Journal of Interactive Marketing, 19(3), 15-37.

Sparks, B. A., \& Browning, V. (2011). The impact of online reviews on hotel booking intentions and perception of trust. Tourism Management, 32(6), $1310-1323$.

Sparks, B. A., Perkins, H. E., \& Buckley, R. (2013). Online travel reviews as persuasive communication: the effects of content type, source, and certification logos on consumer behavior. Tourism Management, 39(December 2013), 1-9.

Streitfield, D. (2011, August 16). In a race to out-rave, 5-star web reviews go for $\$ 5$. The New York Times. Retrieved from http://www.nytimes.com/2011/08/20/ technology/finding-fake-reviews-online.html?_r=0.

Sussman, S. W., \& Siegal, W. S. (2003). Informational influence in organizations: an integrated approach to knowledge adoption. Information Systems Research, 14(1), 47-65.

Tidwell, L. C. \& Walther, J. B. (2002). Computer-mediated communication effects on disclosure, impressions, and interpersonal evaluations: getting to know one another a bit at a time. Human Communication Research, 28(3) $317-348$.

Trend, N. (2013, October 23). TripAdvisor and the issue of trust. The Telegraph Retrieved from http://www.telegraph.co.uk/travel/travelnews/10399563/Trip Advisor-and-the-issue-of-trust.html.

Tuttle, B. (2012, August 28). Why you shouldn't trust positive online reviews-or negative ones, for that matter. Time. Retrieved from http://business.time.com/ 2012/08/28/why-you-shouldnt-trust-positive-online-reviews-or-negative-onesfor-that-matter/.

Vermeulen, I. E., \& Seegers, D. (2009). Tried and tested: the impact of online hote reviews on consumer consideration. Tourism Management, 30(1), 123-127.

Willemsen, L. M., Neijens, P. C., Bronner, F., \& De Ridder, J. A. (2011). Highly recommended! The content characteristics and perceived usefulness of online consumer reviews. Journal of Computer-Mediated Communication, 17(1), $19-38$.

Yang, Z., Cai, S., Zhou, Z., \& Zhou, N. (2005). Development and validation of an instrument to measure user perceived service quality of information presenting web portals. Information \& Management, 42(4), 575-589.
Ye, Q., Law, R., \& Gu, B. (2009). The impact of online user reviews on hotel room sales. International Journal of Hospitality Management, 28(1), 180-182.

Yoo, K.-H., \& Gretzel, U. (2009). Comparison of deceptive and truthful travel reviews. In W. Höpken, U. Gretzel, \& R. Law (Eds.), Information and communication technologies in tourism 2009 (pp. 37-48). Vienna, Austria: Springer-Verlag.

Yoon, S.-J. (2002). The antecedents and consequences of trust in online-purchase decisions. Journal of Interactive Marketing, 16(2), 47-63.

Zahedi, F., \& Song, J. (2008). Dynamics of trust revision: using health infomediaries. Journal of Management Information Systems, 24(4), 225-248.

Zhang, W., \& Watts, S. A. (2008). Capitalizing on content: information adoption in two online communities. Journal of the Association for Information Systems, 9(2), 73-94.

Zhu, F. \& Zhang, X. (2010). Impact of online consumer reviews on sales: the moderating role of product and consumer characteristics. Journal of Marketing, $74(2), 133-148$.

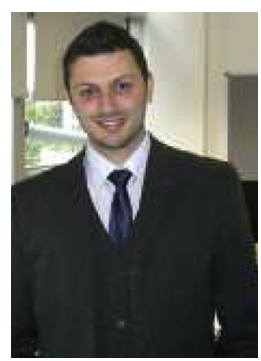

Dr. Raffaele Filieri is a Senior Lecturer in the Marketing, Travel and Tourism Subject Group at Newcastle Business School, Northumbria University, United Kingdom. He received his Ph.D. from Universita' Roma Tre and his postdoc from La Sapienza Universita' di Roma. His main research interests revolve around electronic word of mouth, online trust, e-tourism, and tourism marketing and online consumer cocreation. His papers have been accepted for publication in Journal of Travel Research, Journal of Business Research, Industrial Marketing Management, Journal of Knowledge Management, Expert systems, International Journal of Quality \& Reliability Management, Journal of Business Strategy, Marketing Intelligence \& Planning, International Journal of Agile Systems and Management, Journal of Direct, Data and Digital Marketing Practice. 